\title{
Rheological and thermophysical properties of blackberry juice
}

\author{
Propriedades reológicas e termofísicas de suco de amora
}

\author{
Renato Alexandre Ferreira CABRAL ${ }^{1}$, Carlos Eduardo ORREGO-ALZATE ${ }^{2}$, \\ Ana Lúcia GABAS ${ }^{3 *}$, Javier TELIS-ROMERO ${ }^{1}$
}

\begin{abstract}
Rheological and thermophysical properties were determined for blackberry juice, which was produced from blackberry fruit at $9.1 \pm 0.5{ }^{\circ} \mathrm{Brix}$ and density of $1.0334 \pm 0.0043 \mathrm{~g} \mathrm{~cm}^{-3}$. The concentration process was performed using a roto evaporator, under vacuum, to obtain concentrated juice at about $60^{\circ} \mathrm{Brix}$. In order to obtain different concentrations, concentrated juice was diluted with distilled water. Rheological measurements were carried out using a Rheotest 2.1 Searle type rheometer. In the tested ranges, the samples behaved as pseudoplastic fluids, and the PowerLaw model was satisfactorily fitted to the experimental data. The friction factor was measured for blackberry juice in laminar flow conditions of pseudoplastic behavior. Thermal conductivity, thermal diffusivity and density of blackberry juice at 9.4 to $58.4{ }^{\circ}$ Brix were determined, in triplicate, at 0.5 to $80.8^{\circ} \mathrm{C}$. Polynomial regression was performed to fit experimental data obtaining a good fit. Both temperature and concentration showed a strong influence on thermophysical properties of blackberry juice. Calculated apparent specific heat values varied from 2.416 to $4.300 \mathrm{~kJ} \mathrm{~kg}^{-1}{ }^{\circ} \mathrm{C}$ in the studied interval.

Keywords: fruit juice; rheology; thermal conductivity; thermal properties.
\end{abstract}

\section{Resumo}

As propriedades reológicas e termofísicas foram determinadas para suco de amora produzido a partir da fruta com $9.1 \pm 0.5{ }^{\circ} \mathrm{Brix}$ e densidade de $1,0334 \pm 0,0043 \mathrm{~g} \mathrm{~cm}^{-3}$. O processo de concentração foi realizado utilizando-se um roto evaporador, sob vácuo, obtendo-se o suco concentrado em aproximadamente $60{ }^{\circ}$ Brix. As diferentes concentrações foram obtidas a partir da diluição do suco concentrado em água destilada. As medidas reológicas foram conduzidas utilizando-se o reômetro Rheotest 2.1 do tipo Searle. Em todos os experimentos as amostras apresentaram um comportamento pseudoplástico, e o modelo da Lei da Potência foi ajustado satisfatoriamente aos dados experimentais. $\mathrm{O}$ fator de atrito foi medido para o suco em regime laminar com comportamento pseudoplástico. A condutividade térmica, a difusividade térmica e a densidade foram determinadas em triplicata para o suco de amora nas faixas de 9,4 a $58,4{ }^{\circ} \mathrm{Brix}$ e de 0,5 a $80,8{ }^{\circ} \mathrm{C}$. A temperatura e a concentração mostraram forte influência nas propriedades termofísicas do suco de amora. Os valores do calor específico aparente variaram de 2,416 a $4,300 \mathrm{~kJ} \cdot \mathrm{kg}^{-1}{ }^{\circ} \mathrm{C}$.

Palavras-chave: condutividade térmica; propriedades térmicas; reologia; suco de fruta.

\section{Introduction}

The fruit juice industry has become one of the world's biggest agribusinesses. Although Brazil is the main exporter, there are many other medium and underdeveloped countries in the fruit juice and pulp market.

Blackberry (Mora de Castilla: Rubus glaucus Benth) is a fruit originally from the high tropical areas of America and is widely cultivated in Colombia, Venezuela, Ecuador, Guatemala, El Salvador and Mexico. There are believed to be as many as 300 species of blackberries of relative importance throughout the world which contain proteins, vitamins A, C, K, calcium, phosphorus and potassium. Almost 90\% of international blackberry production is transformed to processed products: nectars and juices, frozen pulp, $65{ }^{\circ} \mathrm{Brix}$ concentrate, jams and jellies, $33^{\circ} \mathrm{Brix}$ concentrated wine and sulfite pulps and dehydrated powders ${ }^{7}$.

Recebido para publicação em 1/9/2006

Aceito para publicação em 18/7/2007 (001842)

'Departamento de Engenharia e Tecnologia de Alimentos,

Universidade Estadual Paulista, CEP 15054-000,

São José do Rio Preto - SP, Brasil

Departamento de Física e Química, Universidade Nacional de Colômbia,

Manizales, A.A. 127, Colômbia

Departamento de Engenharia de Alimentos, Universidade de São Paulo - USP,

CEP 13635-900, CP 23, Pirassununga-SP, Brasil,

E-mail: gabas@usp.br

* A quem a correspondência deve ser enviada
The present positive trend of the fruit juice industry, which stems from the non-alcoholic beverage market, is to improve and automate fruit juice production plants. During processing, the fruit juice industry deals with juice in a variety of concentrations and temperatures and is submitted to unit operations such as pumping, heat exchange, evaporation, spray-drying and others. In order to have a suitable process design, operation and control, knowledge of thermophysical and rheological behavior of the fruit juice as affected by water fraction and temperature are of fundamental importance.

Density $(\rho)$, thermal conductivity (k), thermal diffusivity $(\alpha)$ and heat capacity $(\mathrm{Cp})$, are the major thermophysical properties (TPP) required to evaluate, design and model heat transfer processes, such as refrigeration, freezing, heating or drying. According to BECKER and FRICKE ${ }^{3}$ and MCMINN and MAGEE ${ }^{17}$, empirical models applied to predict the TPP of foods are effective in contrast to models derived from theoretical bases. As chemical composition and temperature can strongly affect the TPP of foods, these variables are commonly taken into account to develop the above mentioned mathematical functions ${ }^{3,17,23}$.

TPP and rheological studies have been reported for several liquid foods, common juices such as orange ${ }^{15,21,24}$; apple ${ }^{9}$ and tomato $^{8}$; yogurt ${ }^{23} ;$ milk $^{19,22,27}$ and coffee extract ${ }^{25}$. However, TPP and rheological parameters for blackberry juice are inexistent in the literature and to obtain these data is quite important for adequate equipment design. The aim of this work was 
to measure the thermal conductivity, thermal diffusivity and density of blackberry juice as a function of the extensive range of temperature and juice concentration and to obtain simple equations to correlate experimental data. Additionally, in order to validate the rheological data, they were used to calculate friction factors for tube flow based on widely accepted correlations. These results were then compared with those determined from experimental values of pressure loss in tubes.

\section{Materials and methods}

\subsection{Material}

All the experimental measurements were conducted in samples from the same batch of concentrated blackberry juice (60.0 $\left.{ }^{\circ} \mathrm{Brix}\right)$. The concentration process was performed using a roto evaporator, under vacuum, to obtain concentrated juice. In order to obtain different concentrations, concentrated juice was diluted with distilled water. Blackberry juice was extracted from blackberries with the following characteristics: $(9.1 \pm 0.5){ }^{\circ} \mathrm{Brix}$, density, (1.0334 \pm 0.0043$) \mathrm{gcm}^{-3},(45.4 \pm 0.9) \mathrm{g} .100 \mathrm{~g}^{-1} \mathrm{pulp}$ content and $\mathrm{pH}(2.94 \pm 0.05)^{1}$.

\subsection{Thermal conductivity}

Thermal conductivity at various temperatures and water contents were measured using the method described by BELLET et al. ${ }^{4}$, based on a cylindrical cell, where the liquid whose properties are determined fills the annular space between two concentric cylinders. The physical characteristic is specified in Figure 1, which presents: two coaxial copper cylinders ( $a$ and b), $180 \mathrm{~mm}$ in length, separated by a $2 \mathrm{~mm}$ annular space, which was filled with the sample; $50 \mathrm{~mm}$ thick covers (c) made of a low thermal conductivity material $\left(0.225 \mathrm{~W} \cdot \mathrm{m}^{-1}{ }^{\circ} \mathrm{C}\right)$ to prevent axial heat transfer; a heater made with a constantan wire (resistance $15 \mathrm{~W}$ ), electrically insulated by a varnish and coiled around a copper stick; two thermocouples type $\mathrm{T}$ to measure the temperature differences between the two cylinders, located at half the length of the cell, with wires placed inside $0.5 \mathrm{~mm}$ gaps, parallel to the cell axis. The external diameters of the outer and inner copper cylinders were, respectively, 34 and $20 \mathrm{~mm}$, while the internal diameters were 24 and $10 \mathrm{~mm}$ for the outer and inner cylinders, respectively. To keep the external temperature constant, the cell was immersed in a thermostatic bath (model MA-184, Marconi, São Paulo, Brazil) containing ethyl alcohol. The power input to the heater resistance was from a laboratory DC power supply (model MPS-3006D, Minipa, São Paulo, Brazil), which adjusted the current with a stability of 0.05\%. An HP data logger, model 75.000-B, an HP-IB interface and an HP PC running a data acquisition program written in IBASIC, monitored the temperatures with an accuracy of $0.6{ }^{\circ} \mathrm{C}$. In order to measure the temperature, one and three copperconstantan thermocouples were embedded in the surfaces of the inner and outer cylinders, respectively. The cell was calibrated with distilled water. Details of this method, cell calibration and experimental tests can be found elsewhere $\mathrm{e}^{4,19,25}$.

In the steady state, conduction inside the cell was described by the Fourier equation in cylindrical coordinates, with boundary conditions corresponding to heat transfer between two

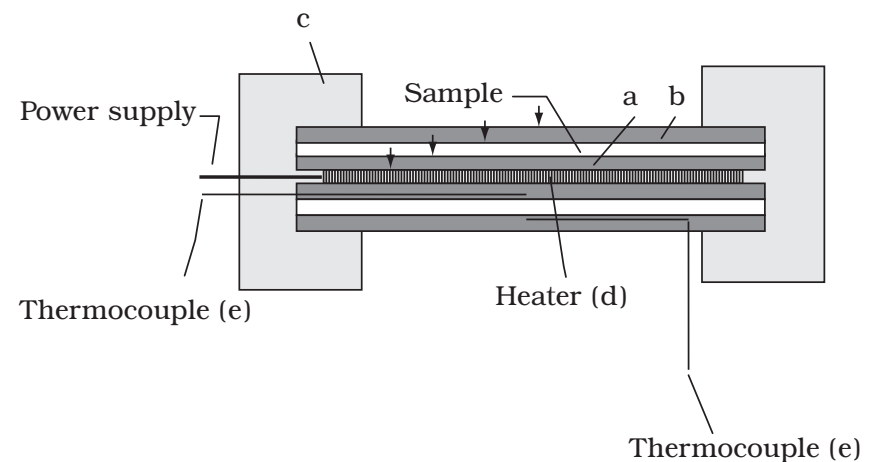

Figure 1. Cross section of the cell used for thermal conductivity and specific heat measurements.

concentric cylindrical surfaces kept at constant temperatures, as given by Equations 1 to 3 .

$$
\begin{gathered}
\frac{\partial \dot{\mathrm{q}}}{\partial \mathrm{S}}=-\mathrm{k}(\mathrm{T}) \frac{\partial \mathrm{T}}{\partial \mathrm{r}} \\
\mathrm{T}\left(\mathrm{r}=\mathrm{R}_{1}\right)=\mathrm{T}_{1} \\
\mathrm{~T}\left(\mathrm{r}=\mathrm{R}_{2}\right)=\mathrm{T}_{2}
\end{gathered}
$$

where $\dot{q}$ is the heat flux in the thermal resistance (W); $\mathrm{S}$ is the surface area of a cylinder of radius $r\left(\mathrm{~m}^{2}\right)$; $\mathrm{k}$ is the thermal conductivity of the sample at an average temperature $(\mathrm{T} 1+\mathrm{T} 2) / 2$ $\left(\mathrm{W} . \mathrm{m}^{-1} .{ }^{\circ} \mathrm{C}\right)$; $\mathrm{T}$ is the temperature $\left({ }^{\circ} \mathrm{C}\right) ; \mathrm{r}$ is the radius $(\mathrm{m}) ; \mathrm{R} 1$ and $\mathrm{R} 2$ is the external and internal radius of the internal and external cylinder, respectively; $\mathrm{T} 1$ is the steady state temperature in the internal cylinder $\left({ }^{\circ} \mathrm{C}\right) ; \mathrm{T}_{2}$ is the steady state temperature in the thermostatic bath where the cell was immersed $\left({ }^{\circ} \mathrm{C}\right)$.

Equation 1 was integrated in the form:

$\mathrm{k}=\dot{\mathrm{q}} \frac{\log \left(\mathrm{R}_{2} / \mathrm{R}_{1}\right)}{2 \pi\left(\mathrm{T}_{1}-\mathrm{T}_{2}\right)}$

whereby the sample thermal conductivity, $\mathrm{k}$ was calculated.

\subsection{Thermal diffusivity}

Thermal diffusivity was determined using the method proposed by DICKERSON ${ }^{16}$. The experimental apparatus consisted of a cylindrical cell $\left(24.75 \times 10^{-3} \mathrm{~m}\right.$ internal radius and $248.5 \times 10^{-3} \mathrm{~m}$ length) made of chromium plated brass with two nylon covers with thermal diffusivity of $1.09 \times 10^{-7} \mathrm{~m}^{2} / \mathrm{s}$, which is similar to most liquid food products. Two thermocouples type $\mathrm{T}$ were fixed at the center and on the external surface of the cell. The cell was immersed in a well-agitated thermostatic bath (MK70, MLW, Dresden, Germany) heated at a constant rate, and the development of temperatures at the wall and at the center of the cell was monitored. Temperatures were monitored using the same data acquisition system used in thermal conductivity measurements.

The calculations were based on the solution of the equation of energy conservation, considering an unsteady state, constant 
unidimensional (radial) heat flux, subjected to the following boundary conditions:

$\mathrm{T}=\mathrm{T}_{\mathrm{R}}=\mathrm{At}, \mathrm{t}>0, \mathrm{r}=\mathrm{R}$

$\frac{\partial \mathrm{T}}{\partial \mathrm{t}}=0, \mathrm{t}>0, \mathrm{r}=0$

The value of the experimental thermal diffusivity $\left(\alpha_{\text {exp }}\right)$ is given by:

$\left(\mathrm{T}_{\mathrm{R}}-\mathrm{T}_{0}\right)=\frac{\mathrm{AR}^{2}}{4 \alpha_{\exp }}$

where $\left(T_{R}-T_{0}\right)$ is the temperature difference between the center and the surface of the sample, and $\mathrm{A}$ is the constant heating rate. For each experiment a plot of $T_{R}$ and $T_{0}$ versus time was constructed. The heating rate was obtained from the slope of the $T_{R}$ versus $t$ curve, and $\left(T_{R}-T_{0}\right)$ was evaluated from the difference between $T_{R}$ and $T_{0}$ curves after eliminating the initial transient.

\subsection{Density}

The density of blackberry juice at different temperatures and concentrations was determined in triplicate by weighing (on scales) the juice contained in a standard volumetric pycnometer ${ }^{9}$. The sample temperature was varied by equilibration in a thermostatic bath. The pycnometer of $25 \mathrm{~mL}$ was previously calibrated with distilled water at each temperature.

\subsection{Specific heat}

The specific heat was directly calculated from the following equation:

$\mathrm{C}_{\mathrm{p}}=\frac{\mathrm{k}}{\rho \times \alpha}$

where $\rho=$ density $\left(\mathrm{kg} \cdot \mathrm{m}^{-3}\right)$ and $\alpha=$ thermal diffusivity $\left(\mathrm{m}^{2} / \mathrm{s}\right)$.

\subsection{Rheological measurements and flow characterization}

Rheological measurements were carried out using a Rheotest 2.1 (VEB -MLW Prüfgeräte- Werk, Germany) Searle type rheometer, equipped with a coaxial cylinder sensor system (radii ratio of 1.06). The instrument can be operated at 44 different speeds, which are changed stepwise with a selector switch. The speed of the rotating cylinder varied from 0.028 to $243 \mathrm{rpm}$. A thermostatic bath (model MA-184, Marconi) containing ethyl alcohol was used to control the working temperature within the range of 0.5 to $80.8{ }^{\circ} \mathrm{C}$. Shear stress values at the surface of the internal cylinder were obtained by multiplying torque readings by the rheometer constant, whereas the shear rate values were evaluated according to KRIEGER and ELROD ${ }^{16}$. The widely known empirical expression for the stress tensor, the Power-Law model, was used to describe the flow behavior of blackberry juices. For the Power-Law model, the local shear stress depends on the local shear rates as follows ${ }^{6}$ :

$$
\tau_{\mathrm{rz}}=-\mathrm{K}\left|\frac{\mathrm{dv}_{\mathrm{z}}}{\mathrm{dr}}\right|^{\mathrm{n}-1}\left(\frac{\mathrm{dv}_{\mathrm{z}}}{\mathrm{dr}}\right)
$$

where $\tau_{\mathrm{rz}}(\mathrm{Pa})$ is the local shear stress, $\mathrm{K}\left(\mathrm{Pa} . \mathrm{s}^{\mathrm{n}}\right)$ is the consistency index, $\mathrm{n}$ (dimensionless) is the flow behavior index and $\mathrm{dv} / \mathrm{dr}\left(\mathrm{s}^{-1}\right)$ is the local shear rate.

\subsection{Pressure drop measurements in pipe flow}

The apparatus specified in full details by TELIS-ROMERO et al. ${ }^{26}$ was used to measure pressure loss during laminar pipe flow of blackberry juices. It consists of a heat transfer, a circular section, which is submerged in a large thermostatic bath (model MA-184, Marconi Equipamentos para Laboratório Ltda., SP, Brasil) containing water at a constant temperature. Flow experiments were carried out when the samples by the solution in the thermostatic bath were heated. The equipment was made with two horizontal steel circular tubes with nominal diameters of $3 / 4$ in and $11 / 2$ in, connected to a stainless steel cylindrical tank with a capacity of $270 \mathrm{~L}$. The total length of the section was $1.2 \mathrm{~m}$ providing a maximum length-to-diameter ratio $(L / D)$ of 54.8. A distance of $1.50 \mathrm{~m}$ provided the developing length of the flow regime for all experimental tests. Differential pressure transmitters (model LD-301, Smar Equipamentos Industriais Ltda., SP, Brasil) connected to pipes were used to measure static pressure in the equipment. Temperature transducers (model TT-302, Smar Equipamentos Industriais Ltda., SP, Brasil) were used to measure the temperature at the beginning and at the end of the test section. The less concentrated blackberry juices were pumped by means of a peripheral pump (model P-500, KSB Bombas Hidráulicas S.A., SP, Brasil), while the most concentrated used a gear pump (model Triglav, KSB Bombas Hidráulicas S.A., SP, Brasil). A static mixer was placed at the end of the equipment to homogenize the final temperature of the juices. A flow meter (model LD100, MLW Prüfgeräte-Werk, Germany) was used to initially adjust the desired flow rate in each experiment, but exact measures were obtained by weighing fluid samples collected at determined time intervals. A HP data logger model 75.000-B, an interface HP-IB and an HP PC running a data acquisition and control program written in IBASIC monitored temperatures and pressures. The tested samples were blackberry juices containing $9.3,24.3$ and $34.6{ }^{\circ} \mathrm{Brix}$. The average flow velocities varied from 0.05 to $2.50 \mathrm{~m} . \mathrm{s}^{-1}$, totalizing one hundred experimental values of pressure loss for each sample.

\subsection{Evaluation of friction factors in pipe flow}

The friction factor for an incompressible fluid moving in a straight pipe of a uniform cross section may be written in terms of pressure loss, as given by Equation 10 . The quantity $f_{\text {exp }}$ calculated from experimental data on pressure loss is sometimes called the Fanning friction factor ${ }^{6}$.

$\mathrm{f}_{\exp }=\frac{\Delta \mathrm{PD}}{2 \rho \overline{\mathrm{v}}_{\mathrm{Z}}^{2} \mathrm{~L}}$

in which $\rho\left(\mathrm{kg} \cdot \mathrm{m}^{-3}\right)$ is the fluid density, $\overline{\mathrm{v}}_{\mathrm{z}}\left(\mathrm{m} \cdot \mathrm{s}^{-1}\right)$ is the average axial flow velocity, $\mathrm{D}(\mathrm{m})$ is the tube diameter and $\Delta \mathrm{P}(\mathrm{Pa})$ is the 
pressure drop observed in a length $\mathrm{L}(\mathrm{m})$ of the tube. For the fully developed laminar pipe flow of Power-Law fluids, the friction factor is given by an analogous expression of the well-known dimensionless form of the Hagen-Poiseuille equation ${ }^{11}$ :

$\mathrm{f}_{\text {theo }}=\frac{16}{\operatorname{Re}_{\mathrm{mr}}}$

in which $\mathrm{f}_{\text {theo }}$ is the friction factor estimated theoretically and $\mathrm{Re}_{\mathrm{mr}}$ is the Reynolds number defined by METZNER and REED ${ }^{18}$. By using the Power-Law model for simple ducts, such as the circular pipe, it is possible to analytically solve the momentum equation and to obtain the generalized Reynolds number defined by METZNER and REED ${ }^{18}$ :

$\operatorname{Re}_{m r}=\left(\frac{\rho \bar{v}_{z}^{2-n} D^{n}}{8^{n-1} K}\right)\left(\frac{4 n}{1+3 n}\right)^{n}$

in which $\mathrm{K}$ is the consistency index $\left(\mathrm{Pa} . \mathrm{S}^{\mathrm{n}}\right)$ and $\mathrm{n}$ is the flow behavior index (dimensionless).

\subsection{Data analysis}

Fitted models were obtained by using estimation procedures from statistical program Statgraphics v. 4.0. The suitability of the fitted models was evaluated by determining the coefficient $\left(r^{2}\right)$, the significance level $(p<0.05)$ and residual analysis.

\section{Results and discussion}

\subsection{Thermophysical properties}

The thermal conductivity, thermal diffusivity and density of blackberry juice at 9.4, 20.0, 25.2, 29.4, 33.0, 40.2, $46.1,50.3,54.6$ and $58.4{ }^{\circ}$ Brix were determined, in triplicate, at $0.5,9.3,22.4,31.3,42.0,54.1,66.7$ and $80.8{ }^{\circ} \mathrm{C}$, adding up to 160 experimental values for each property. Polynomial regression was performed to fit experimental data, presented in the following Equations 13 to 15:

$\mathrm{k}=0.592+10.97 \times 10^{-4} \times \mathrm{T}-3.61 \times 10^{-3} \times \mathrm{C}$

$r^{2}=0.993$

$\alpha=1.43 \times 10^{-7}+1.63 \times 10^{-10} \mathrm{~T}-2.31 \times 10^{-10} \mathrm{C}$

$\mathrm{r}^{2}=0.949$

$\rho=955.4-0.513 \times \mathrm{T}+5.725 \times \mathrm{C}$

$r^{2}=0.966$

$0.5^{\circ} \mathrm{C} \leq \mathrm{T} \leq 80.8^{\circ} \mathrm{C} \quad 9.4 \leq \mathrm{C} \leq 58.4 \leq{ }^{\circ} \mathrm{Brix}$

Figure 2 shows the experimental data of blackberry juice thermal conductivity and compares them with the predicted values in Equation 13.

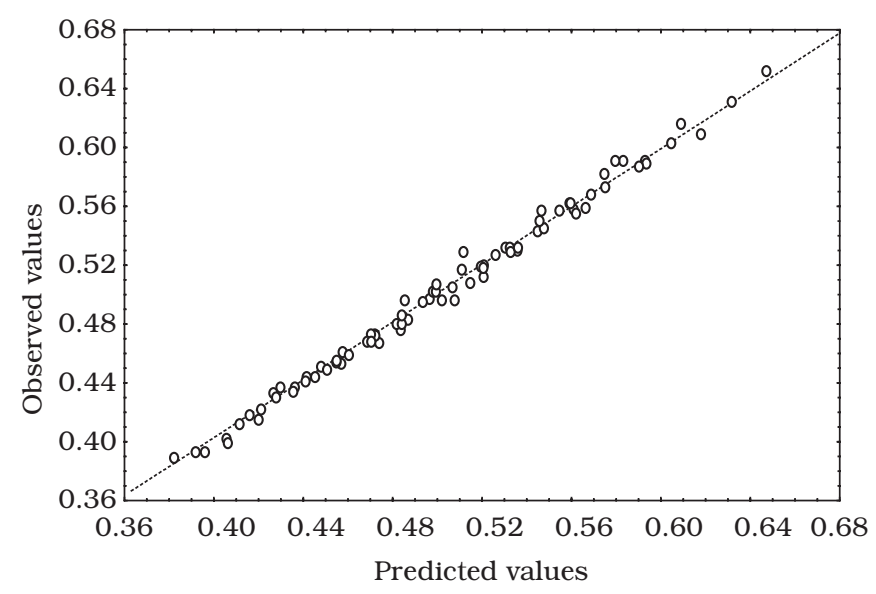

Figure 2. Experimental data of blackberry juice thermal conductivity versus thermal conductivity predicted from Equation 13.

Multiple regression analysis indicated a dependence of thermal conductivity of blackberry juice related to concentration and with a minor influence with temperature $(\mathrm{p}<0.01)$. TELIS-ROMERO et al. ${ }^{24}$ found similar values for orange juice. It can be observed that it is compatible with experimental data and the predictions of Equation 13. Comparison with correlations proposed for orange juice at $40{ }^{\circ} \mathrm{C}$ by TELIS-ROMERO et al. ${ }^{24}$ and for juices by BHUMBLA et al.$^{5}$, indicated a similarity between orange juice and blackberry juice.

Figure 3 shows the experimental data of blackberry juice thermal diffusivity and compares them with the predicted values in Equation 14. Multiple regression analysis indicated a dependence of thermal diffusivity of blackberry juice related to concentration and temperature $(p<0.01)$. It can be observed that the experimental data of thermal diffusivity did not fit as

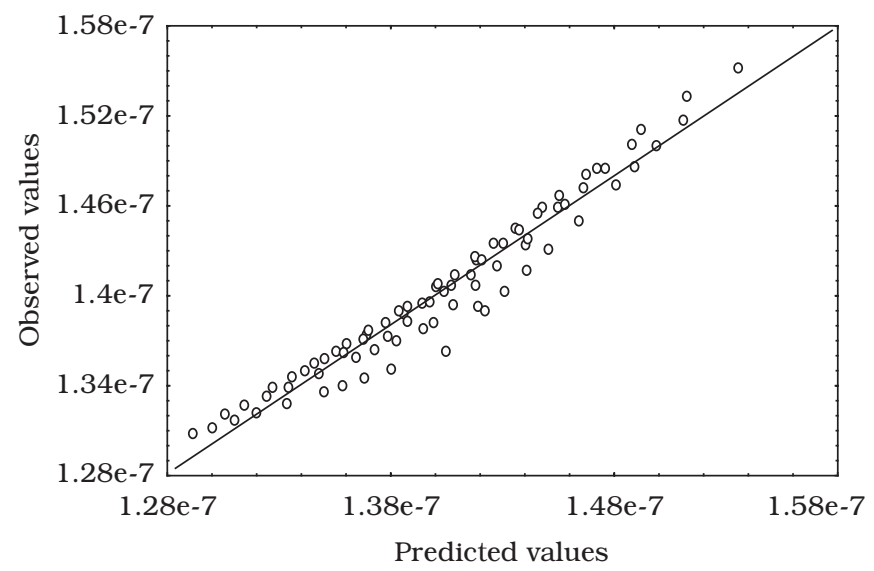

Figure 3. Experimental data of blackberry juice thermal diffusivity versus thermal diffusivity predicted from Equation 14.

well as other properties. The predictive model for orange juice proposed by TELIS-ROMERO et al. ${ }^{24}$ was compatible with the equation parameters $\left(\mathrm{R}^{2}>0.97\right)$ and goodness of fit. 


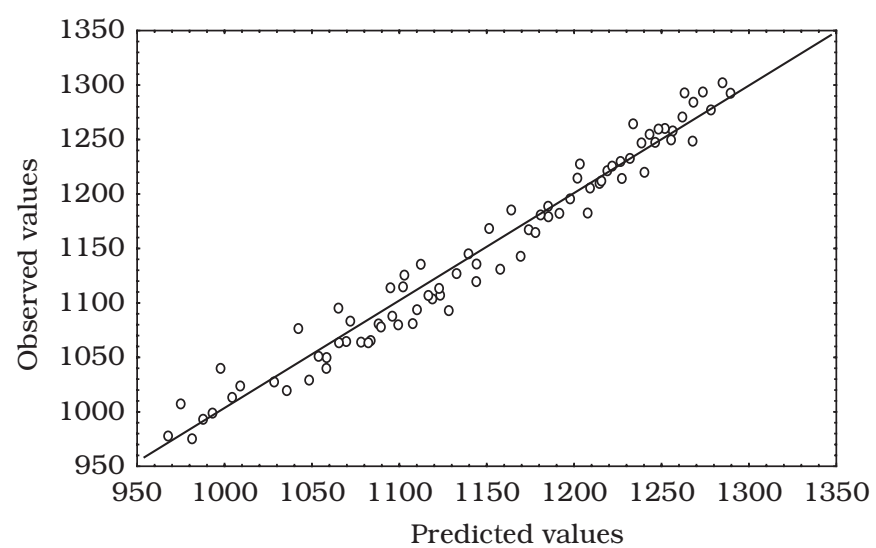

Figure 4. Experimental data of blackberry juice density versus density predicted from Equation 15.

Experimental data of blackberry juice density compared to the predicted values in Equation 15 can be seen in Figure 4 . Multiple regression analysis indicated a strong dependence of density of blackberry juice related to concentration and temperature.

\subsection{Specific heat}

The specific heat was calculated according to Equation 8, using 160 experimental data for each thermophysical property. Table 1 shows the average data obtained in the experimental assays for thermal conductivity, density, thermal diffusivity and calculated specific heat as a function of temperature and concentration of blackberry juice.

\subsection{Flow behavior}

Rheograms of blackberry juice were obtained in the range of shear rates from $12.4 \mathrm{~s}^{-1}$ to $489.3 \mathrm{~s}^{-1}$. In the tested ranges, the samples behaved as pseudoplastic fluids, and the PowerLaw model was satisfactorily fitted to the experimental data, with $0.988 \leq \mathrm{r}^{2} \leq 0.999$ and a root mean square (RMS) between $0.83 \leq$ RMS (\%) 3.50. The Herschel-Bulkley model was also fitted to the experimental data and provided good statistical results $\left(r^{2} \cong 0.999\right.$ and $\left.\mathrm{RMS} \cong 1.0 \%\right)$ since it is a three-parameter model, although the yield stress values were negative, which is meaningless from a physical standpoint. POLIZELLI et al. ${ }^{20}$ also obtained negative yield stress values in the rheological characterization of aqueous solutions of sucrose and xanthan gum.

Table 1. Thermal conductivity, density and thermal diffusivity experimental data and calculated specific heat from Equation 8 as a function of temperature and concentration of blackberry juice.

\begin{tabular}{|c|c|c|c|c|c|c|c|c|c|c|c|}
\hline \multirow[t]{2}{*}{ Property } & \multirow[t]{2}{*}{$\mathrm{T}\left({ }^{\circ} \mathrm{C}\right)$} & \multicolumn{10}{|c|}{ Concentration $\left({ }^{\circ} \mathrm{Brix}\right)$} \\
\hline & & 9.4 & 20.0 & 25.2 & 29.4 & 33.0 & 40.2 & 46.1 & 50.3 & 54.6 & 58.4 \\
\hline \multirow{8}{*}{$\begin{array}{l}\mathrm{k} \\
\left(\mathrm{W} \cdot \mathrm{m}^{-1}{ }^{\circ} \mathrm{C}\right)\end{array}$} & 0.5 & 0.562 & 0.520 & 0.496 & 0.483 & 0.467 & 0.451 & 0.433 & 0.412 & 0.393 & 0.389 \\
\hline & 9.3 & 0.568 & 0.532 & 0.529 & 0.497 & 0.476 & 0.461 & 0.437 & 0.422 & 0.402 & 0.393 \\
\hline & 22.4 & 0.591 & 0.543 & 0.527 & 0.517 & 0.502 & 0.473 & 0.449 & 0.434 & 0.415 & 0.399 \\
\hline & 31.3 & 0.591 & 0.557 & 0.530 & 0.512 & 0.496 & 0.480 & 0.459 & 0.444 & 0.437 & 0.418 \\
\hline & 42.0 & 0.603 & 0.559 & 0.545 & 0.532 & 0.519 & 0.495 & 0.472 & 0.453 & 0.444 & 0.430 \\
\hline & 54.1 & 0.609 & 0.591 & 0.558 & 0.550 & 0.529 & 0.505 & 0.496 & 0.473 & 0.454 & 0.441 \\
\hline & 66.7 & 0.631 & 0.589 & 0.582 & 0.562 & 0.557 & 0.518 & 0.502 & 0.480 & 0.468 & 0.455 \\
\hline & 80.8 & 0.652 & 0.616 & 0.587 & 0.573 & 0.555 & 0.532 & 0.508 & 0.507 & 0.486 & 0.468 \\
\hline \multirow{7}{*}{$\begin{array}{l}\rho \\
\left(\mathrm{kg} \cdot \mathrm{m}^{-3}\right)\end{array}$} & 0.5 & 1023.8 & 1064.5 & 1080.0 & 1107.2 & 1119.6 & 1179.1 & 1221.3 & 1254.8 & 1248.4 & 1292.5 \\
\hline & 9.3 & 1013.3 & 1095.3 & 1113.9 & 1103.8 & 1145.0 & 1180.9 & 1209.8 & 1246.7 & 1292.7 & 1302.1 \\
\hline & 22.4 & 1040.0 & 1049.8 & 1080.6 & 1135.5 & 1127.0 & 1167.3 & 1182.5 & 1232.7 & 1257.9 & 1277.1 \\
\hline & 31.3 & 998.7 & 1051.0 & 1065.4 & 1081.1 & 1092.9 & 1142.9 & 1227.5 & 1214.3 & 1260.1 & 1293.6 \\
\hline & 42.0 & 993.0 & 1029.2 & 1064.1 & 1114.8 & 1113.2 & 1185.3 & 1195.5 & 1225.5 & 1247.3 & 1284.3 \\
\hline & 66.7 & 1007.2 & 1019.4 & 1063.5 & 1078.0 & 1093.8 & 1168.4 & 1188.6 & 1205.5 & 1264.5 & 1249.8 \\
\hline & 80.8 & 977.8 & 1027.3 & 1039.8 & 1063.5 & 1125.6 & 1135.8 & 1164.6 & 1214.5 & 1229.8 & 1259.7 \\
\hline \multirow{8}{*}{$\begin{array}{l}\alpha \times 10^{-7} \\
\left(\mathrm{~m}^{2} / \mathrm{s}\right)\end{array}$} & 0.5 & 1.363 & 1.351 & 1.345 & 1.340 & 1.336 & 1.328 & 1.322 & 1.317 & 1.312 & 1.308 \\
\hline & 9.3 & 1.393 & 1.378 & 1.370 & 1.364 & 1.359 & 1.348 & 1.339 & 1.333 & 1.327 & 1.321 \\
\hline & 22.4 & 1.434 & 1.414 & 1.403 & 1.395 & 1.388 & 1.374 & 1.363 & 1.355 & 1.346 & 1.339 \\
\hline & 31.3 & 1.459 & 1.435 & 1.424 & 1.414 & 1.406 & 1.390 & 1.377 & 1.368 & 1.358 & 1.350 \\
\hline & 42.0 & 1.485 & 1.459 & 1.445 & 1.435 & 1.426 & 1.408 & 1.393 & 1.382 & 1.371 & 1.362 \\
\hline & 54.1 & 1.511 & 1.481 & 1.467 & 1.455 & 1.444 & 1.424 & 1.407 & 1.396 & 1.383 & 1.373 \\
\hline & 66.7 & 1.533 & 1.501 & 1.485 & 1.472 & 1.461 & 1.438 & 1.420 & 1.407 & 1.394 & 1.382 \\
\hline & 80.8 & 1.552 & 1.517 & 1.500 & 1.486 & 1.474 & 1.450 & 1.431 & 1.417 & 1.403 & 1.390 \\
\hline \multirow{6}{*}{$\begin{array}{l}\mathrm{Cp} \\
\left(\mathrm{J} . \mathrm{kg}^{-1}{ }^{\circ} \mathrm{C}\right)\end{array}$} & 0.5 & 4052.5 & 3665.2 & 3476.3 & 3323.7 & 3201.5 & 2972.8 & 2788.1 & 2617.3 & 2525.7 & 2430.9 \\
\hline & 9.3 & 4041.5 & 3574.2 & 3500.6 & 3358.7 & 3140.9 & 2981.7 & 2795.1 & 2652.0 & 2483.5 & 2416.2 \\
\hline & 22.4 & 3973.8 & 3681.2 & 3503.5 & 3311.9 & 3258.2 & 3016.5 & 2861.8 & 2696.5 & 2568.0 & 2459.1 \\
\hline & 31.3 & 4060.9 & 3708.6 & 3519.7 & 3385.6 & 3267.7 & 3073.7 & 2807.8 & 2757.2 & 2651.8 & 2508.1 \\
\hline & 66.7 & 4090.6 & 3851.5 & 3691.8 & 3557.1 & 3502.0 & 3136.6 & 3034.0 & 2906.9 & 2757.4 & 2725.0 \\
\hline & 80.8 & 4300.3 & 3953.5 & 3765.6 & 3638.9 & 3385.5 & 3269.2 & 3102.1 & 3011.7 & 2898.7 & 2770.6 \\
\hline
\end{tabular}


The experimental shear rate and shear stress for blackberry juices which have $29.4{ }^{\circ}$ Brix are presented in Figure 5; similar rheograms at the same temperatures were obtained for the other samples. The shear rates were nearly as constant as the temperature which was increased from 0.5 to $80.8^{\circ} \mathrm{C}$.

The fitting of Equation 9 to the experimental data made it possible to evaluate $\mathrm{K}$ and $\mathrm{n}$, which are presented in Table 2 . The Power-Law is a very simple empirical model extensively used for engineering calculations due to its simplicity of having only two parameters. It has been used for describing many liquid foods, such as yellow mombin ${ }^{2}$, soursop juice ${ }^{13}$, orange juice concentrate $^{10}$, egg yolk ${ }^{14}$, coffee extract ${ }^{25}$ and many other fluids.

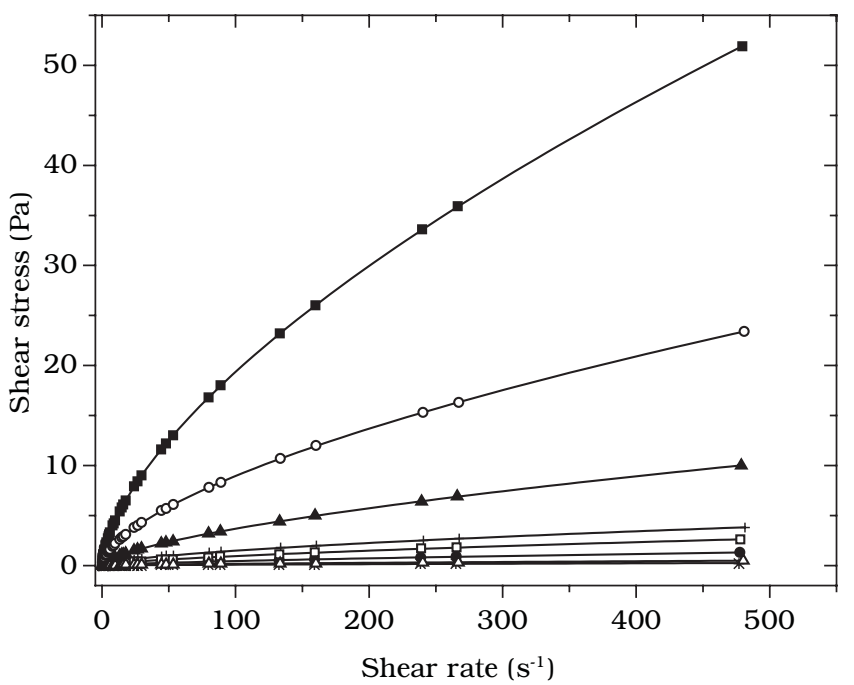

Figure 5. Rheograms of blackberry juice having $29.4^{\circ} \mathrm{Brix}$ at various temperatures. Experimental values: (ロ) $0.5^{\circ} \mathrm{C},(\mathbf{\Delta}) 9.3^{\circ} \mathrm{C},(+) 22.4^{\circ} \mathrm{C}$, (口) $31.3^{\circ} \mathrm{C},\left({ }^{*}\right) 42.0{ }^{\circ} \mathrm{C},(\bullet) 54.1{ }^{\circ} \mathrm{C},(\triangle) 66.7^{\circ} \mathrm{C}$ and $(-) 80.8{ }^{\circ} \mathrm{C}$. Predicted values: (-) Power-Law model, Equation 9.
A non linear regression analysis was performed to obtain a combined effect of temperature and concentration on the consistency index. Combining the Arrhenius and power law relationship derived a single equation, as follows:

$K=9.433 \times 10^{-19} \times C^{6.61} \times \exp \left(\frac{44343.5}{8.315 \times(T+273)}\right)$

$r^{2}=0.987$

Regression analysis was also performed to obtain the effect of concentration and temperature on the flow behavior index, as follows:

$\mathrm{n}=8.44 \times 10^{-1} \times \exp \left(-7.89 \times 10^{-4} \times \mathrm{C}\right) \times$

$\exp \left(\frac{-630.9}{8.315 \times(\mathrm{T}+273)}\right)$

$r^{2}=0.935$

This relationship denotes that an increase in concentration was accompanied by an increase in pseudoplasticity, shown by a decrease in values of $n$.

\subsection{Fanning factor}

Tube flow experiments were carried out when blackberry juice was heated and the experimental pressure loss data were used to calculate the friction factor, according to Equation 10. Densities were evaluated at the average temperature between the initial and final conditions attained by the juice during flow, using the empirical Equation 15 presented in this study.

Figure 6 shows the experimental friction factor measured for blackberry juice in laminar flow conditions of pseudoplastic behavior. The generalized Reynolds number was calculated with flow parameters obtained from Equations 16 and 17. In this region $(\mathrm{Re}<2000)$ the determination coefficient $\left(\mathrm{r}^{2}=0.935\right)$

Table 2. Rheological properties ( $\mathrm{K}$ and $\mathrm{n}$ ) of blackberry juices.

\begin{tabular}{|c|c|c|c|c|c|c|c|c|c|c|c|}
\hline \multirow[t]{2}{*}{ Property } & \multirow[t]{2}{*}{$\mathrm{T}\left({ }^{\circ} \mathrm{C}\right)$} & \multicolumn{10}{|c|}{ Concentration $\left({ }^{\circ} \mathrm{Brix}\right)$} \\
\hline & & 9.4 & 20.0 & 25.2 & 29.4 & 33.0 & 40.2 & 46.1 & 50.3 & 54.6 & 58.4 \\
\hline \multirow[t]{8}{*}{$\mathrm{K}\left(\mathrm{Pa} \cdot \mathrm{s}^{\mathrm{n}}\right)$} & 0.5 & 0.038 & 0.216 & 0.551 & 1.069 & 2.074 & 6.705 & 19.23 & 37.33 & 81.58 & 147.94 \\
\hline & 9.3 & 0.018 & 0.109 & 0.259 & 0.540 & 0.976 & 3.384 & 9.048 & 18.84 & 38.38 & 74.67 \\
\hline & 22.4 & 0.006 & 0.039 & 0.093 & 0.191 & 0.352 & 1.197 & 3.264 & 6.666 & 13.84 & 26.41 \\
\hline & 31.3 & 0.003 & 0.019 & 0.047 & 0.092 & 0.176 & 0.580 & 1.630 & 3.227 & 6.913 & 12.78 \\
\hline & 42.0 & 0.001 & 0.010 & 0.022 & 0.047 & 0.081 & 0.297 & 0.755 & 1.655 & 3.203 & 6.557 \\
\hline & 54.1 & 0.0007 & 0.004 & 0.011 & 0.022 & 0.040 & 0.137 & 0.373 & 0.761 & 1.580 & 3.015 \\
\hline & 66.7 & 0.0003 & 0.002 & 0.005 & 0.010 & 0.018 & 0.062 & 0.169 & 0.345 & 0.717 & 1.369 \\
\hline & 80.8 & 0.0002 & 0.001 & 0.002 & 0.004 & 0.009 & 0.028 & 0.081 & 0.154 & 0.343 & 0.611 \\
\hline \multirow[t]{7}{*}{$\mathrm{n}(-)$} & 0.5 & 0.614 & 0.609 & 0.606 & 0.629 & 0.627 & 0.624 & 0.621 & 0.619 & 0.617 & 0.573 \\
\hline & 9.3 & 0.644 & 0.595 & 0.636 & 0.610 & 0.608 & 0.605 & 0.584 & 0.600 & 0.580 & 0.620 \\
\hline & 22.4 & 0.607 & 0.634 & 0.600 & 0.642 & 0.597 & 0.593 & 0.634 & 0.589 & 0.629 & 0.603 \\
\hline & 31.3 & 0.657 & 0.639 & 0.636 & 0.603 & 0.632 & 0.641 & 0.638 & 0.636 & 0.634 & 0.632 \\
\hline & 42.0 & 0.662 & 0.657 & 0.642 & 0.652 & 0.638 & 0.622 & 0.619 & 0.617 & 0.615 & 0.594 \\
\hline & 66.7 & 0.674 & 0.623 & 0.640 & 0.619 & 0.649 & 0.613 & 0.642 & 0.609 & 0.607 & 0.649 \\
\hline & 80.8 & 0.680 & 0.674 & 0.626 & 0.670 & 0.655 & 0.664 & 0.648 & 0.659 & 0.657 & 0.610 \\
\hline
\end{tabular}


obtained by Equation 18 was very compatible in terms of experimental and predicted values:

$\mathrm{f}_{\mathrm{f}}=\frac{18.02}{\operatorname{Re}_{\mathrm{g}}}$

This compatibility observed between friction factors calculated from experimental data of pressure losses shown in Figure 6 and those estimated from the measured rheological parameters can be taken as an indication of the reliability of the models obtained to describe the flow behavior (Equations 16-17). These equations have shown to be adequate in expressing the rheological behavior of the blackberry juice in the studied range of temperature.

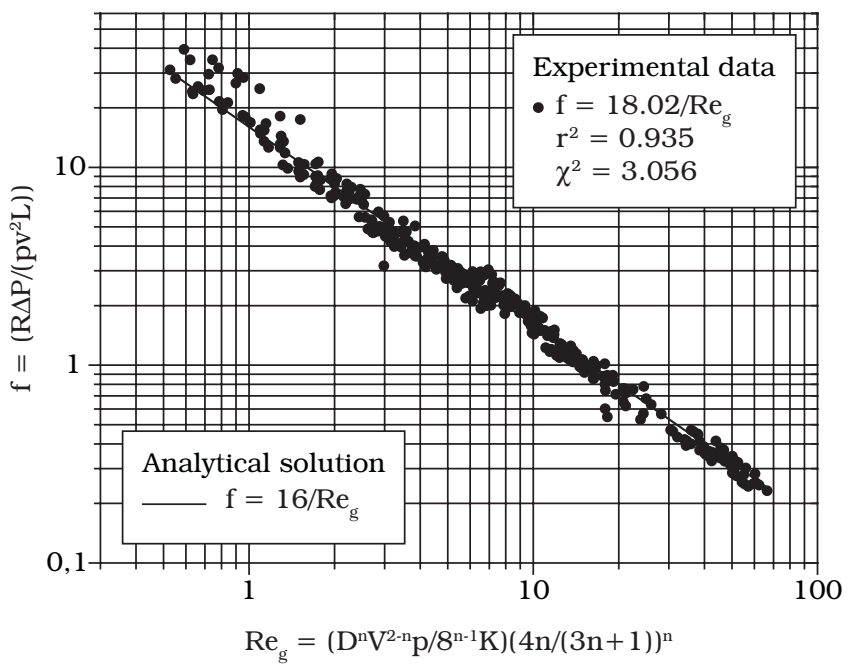

Figure 6. Experimental and prediction friction factors for blackberry juice in laminar flow.

\section{Conclusions}

The thermophysical properties, such as thermal conductivity, density and thermal diffusivity of blackberry juice were determined between 9.4 and $58.4{ }^{\circ} \mathrm{Brix}$ and from 0.5 and $80.8^{\circ} \mathrm{C}$, which are common conditions applied during evaporation processes. Experimental friction factors obtained when blackberry juice flowing through circular tubes is heated were compared with predicted values using the similar Hagen-Poiseuille equation in terms of the generalized Reynolds number. The good compatibility between predicted and observed values confirmed the reliability of the equations proposed for describing the flow behavior of the juice. These results could be used to model heat and mass transfer during concentration of blackberry juice. It is important to emphasize that if these properties were not adequately determined, this could result in under-processing or an incorrect calculation of equipment dimensions.

\section{Acknowledgments}

The authors wish to thank the "Instituto Colombiano para el Desarrollo de la Ciencia y la Tecnología-Colciencias" and the "Conselho Nacional de Pesquisa para o Desenvolvimento Científico e Tecnológico - CNPq" (Process number 474626/2004-0 and 491504/2004-7) for financial support.

\section{References}

1. AOAC. Official Methods of Analysis, $17^{\text {th }}$ edn. Gaithersburg, MD, Washington, 2000.

2. ASSIS, M. M. M. et al. Influence of temperature and concentration on thermophysical properties of yellow mombin (Spondias mombin, L.). European Food Research Technology, v. 223, n. 5, p. 585-593, 2006.

3. BECKER, B. R.; FRICKE, B. A. Food thermophysical property models. Int. Comm. Heat Mass Transfer, v. 26, n. 5, p. 627-636, 1999.

4. BELLET D.; SANGELIN, M.; THIRRIOT, C. Determination des proprietes themophysiques de liquides non-newtniens a l'áide d'une cellule a cylindres coaxiaux. Int. J. Heat Mass Transfer, v. 18, n. 10, p. 1177-1187, 1975.

5. BHUMBLA, V. K.; Singh, A.K.; Singh, Y. Prediction of thermalconductivity of fruit juices by a thermal-resistance model. Journal of Food Science, v. 54, n. 4, p. 1007-1012, 1989.

6. BIRD, R. B.; STEWART, W.E.; LIGHTFOOT, E.N. In: Transport phenomena $2^{\text {nd }}$ edn. John Wiley \& Sons, New York, 2002, $895 \mathrm{p}$.

7. CCI. Corporación Colombia Internacional. Available in: <http:// www.cci.org.co >. Accessed in February 12, 2005.

8. CHOI, Y.; OKOS, M. R. The thermal properties of tomato juice concentrates. Trans. ASAE, v. 26, n. 1, p. 305-311, 1983.

9. CONSTENLA, D. T.; LOZANO, J. E.; Crapiste, G. H. Thermophysical properties of clarified apple juice as a function of concentration and temperature. J. Food Sci., v. 54, n. 3, p. 663-668, 1989.

10. CRANDALl, P. G.; CHEN, C. S.; CARTER, R. D. Models for predicting viscosity of orange juice concentrate. Food Technology, v. 36, n. 5 , p. 245-252, 1982.

11. DARBY, R. Chemical engineering fluid mechanics. $2^{\text {nd }}$ edn. Marcel Dekker, New York, 2001.

12. DICKERSON, R. W. Jr. An apparatus for measurements of thermal diffusivity of foods. Food Technol., v. 19, n. 5, p. 198-204, 1965.

13. GRATÃO, A. C. A.; SILVEIRA JR., V.; TELIS-ROMERO, J. Laminar forced convection to a pseudoplastic fluid food in circular and annular ducts. International Communications in Heat and Mass Transfer, v. 33, n.4, p. 451-457, 2006.

14. GUT, J. A. W. et al. Continuous pasteurization of egg yolk: thermophysical properties and process simulation. Journal of Food Process Engineering, v. 28, n. 2, p. 181-203, 2005.

15. IBARZ, A.; GONZALES, C.; ESPLUGAS, S. Rheology of clarified fruit juices. III: Orange juices. J. Food Eng., v. 21, n. 4, p. 485-494, 1994.

16. KRIEGER, I. M.; ELROD, H. Direct determination of the flow curves of non-Newtonian fluids. B. Shearing rate in the concentric cylinder viscometer. J. Appl. Phys. v. 24, n. 2, p. 134-139, 1953.

17. MCMINN, W. A. M.; MAGEE, T. R. A. Measurement and Prediction of Thermal Properties of Potatoes. Proc. of $11^{\text {th }}$ International Drying Symposium (IDS'98) Greece, August 19-12, A, p. 747-753, 1998.

18. METZNER, A. B.; REED, J. C. Flow of non-Newtonian fluids correlation of the laminar, transition, and turbulent-flow regions. AIChE Journal, v. 1, n. 4, p. 434-440, 1955.

19. MINIM, L. A. et al. Influence of temperature, water and fat contents on the thermophysical properties of milk. J. Chem. Eng. Data., v. 47, n. 6, p. 1488-1491, 2002. 
20. POLIZELLI, M.A. et al. Friction losses in valves and fittings for power-law fluids. Brazilian Journal of Chem. Eng., v. 20, n. 4, p. 455-463, 2003.

21. RAMOS, A. M.; IBARZ, A. Density of juice and fruit puree as a function of soluble solids content and temperature. J. Food Eng., v. 35, n. 1, p. 57-63, 1998.

22. REDDY, CH. S.; Datta, A. K. Thermophysical properties of concentrated reconstituted milk during processing. J. Food Eng., v. 21, n. 1, p. 31-40, 1994.

23. SUK, S. K.; SANTI, R. B. Thermophysical properties of plain yogurt as functions of moisture content. J. Food Eng, v. 32, n. 1, p. 109-124, 1997.
24. TELIS-ROMERO, J. et al. Thermophysical properties of Brazilian orange juice as affected by temperature and water content. $\mathbf{J}$. Food Eng, v. 38, n. 1, p. 27-40, 1998.

25. TELIS-ROMERO, J. et al. Temperature and water content influence on thermophysical properties of coffee extract. Int. Journal of Food Properties, v. 3, n. 3, p. 375-384, 2000.

26. TELIS-ROMERO, J.; TELIS, V. R. N.; YAMASHITA, F. Friction factors and rheological properties of orange juice. J. Food Eng., v. 40, n. 1-2, p. 101-106, 1999.

27. VÉLEZ-RUIZ, J. F.; BARBOSA-CÁNOVAS, G. V. Rheological properties of concentrated milk as function of concentration, temperature and storage time. J. Food Eng., v. 35, n. 2, p. 177-190, 1998. 